\title{
Environmental Metaphors in Contemporary Indonesian Literature
}

\author{
Anas Ahmadi ${ }^{*}$, Abd. Syukur Ghazali ${ }^{2}$ \\ ${ }^{1}$ State University of Surabaya, Lidah Wetan Street, Surabaya, Indonesia \\ ${ }^{2}$ State University of Malang, Semarang Street, Malang, Indonesia
}

Corresponding Author: Anas Ahmadi, E-mail: anasahmadi@unesa.ac.id

\section{ARTICLE INFO}

Article history

Received: October 24, 2017

Accepted: January 30, 2018

Published: May 01, 2018

Volume: 7 Issue: 3

Advance access: March 2018

Conflicts of interest: None

Funding: None

\begin{abstract}
This study is for exploring the environmental metaphor in Indonesian novel. The environmental metaphor is focused on animal and plant metaphors. This study uses qualitative approach and data sources from the novels of Burung-Burung Manyar (2014), Burung-burung Rantau (2014) by YB Mangunwijaya, Mantra Pejinak Ular (2014) by Kuntowijoyo. The data analysis technique that is used refers to the Miles \& Huberman flow model (1994) related to (1) data collection, (2) data reduction, (3) display data, (4) conclusion drawing and revision. The results show that the environmental metaphor has a function to understand the philosophy of human life from the environment and the author's criticism about people who destroy the environment or commit corruptions/evil things.
\end{abstract}

Key words: Metaphor, Environment, Contemporary Indonesian Literature

\section{INTRODUCTION}

Literature as a result of the creative process of the author brings out facts and fiction. Therefore, in literature, there are things that match with the reality, but wrapped with imagination to add aesthetic value. In relation to reality, the literature about environment is currently being discussed. Environmental issues become hot topics in various fields, one of which is literature of Khan (2010:5) shows that the world today is experiencing environmental crisis. Therefore, humans are competing to save the environment in their fields. Authors try to save the environment through the literature they make.

The environment in literature is not described as it is, but it is related to the creative process of the author. Thus, the environment in literature can be in a metaphor about environment, the author's voice about the environment, or author criticism of the present environmental conditions. As expressed by Wales (2011:265), the metaphor in literature appears in figuration form. Therefore, the reader is expected to dismantle the symbol codes.

Literature and environment studies are discussed because of the following factors (1) the emergence of ecocriticism studies, (2) the existence of journals about literature and environment, e.g. ISLE, (3) books about literary and environmental, e.g. the writings of Garrard (2004, 2012), Clark (2011), Love (2003), Estok (2011) which talk about literary relevance in environmental context and (4) discussions/seminars about literature and environment.

The metaphor is about human's interaction with environment. The metaphor is related to the animal in the Indone- sian novel. Indonesian literature as the other country's literature, brings up a metaphor of environment in it. Metaphor of environment cannot be separated from the meaning of philosophical, psychological, and sociological lives of Indonesian people.

The environmental metaphor that appears in the literature cannot be separated from the writer who strives for environment through their literary works. As authors, they contribute to the environment. Certainly, in this case, the environmental saving efforts undertaken by authors are generated in environmental-related dictions. Relating to the environmental metaphor, this article describes the environmental metaphors about animals and plants.

\section{THEORETICAL}

Metaphors in literary is included in stylistic study. Punter (2007) explains that metaphor is used to give a figurative meaning. One of the fields that uses metaphor is literature. In metaphor, the use of the word/phrase is literally refer to one thing, but point to something else (Abrams, 1999:97-98). In literature, metaphor can be used explicitly or implicitly. The appearance of the metaphor can be through the form of noun, adjective, or verb in words, sentences, or paragraphs. The metaphors in the literature bring aesthetical value in literary because the language has a 'taste' so it can kindle the literature.

In the literary context, the environment metaphors may be related to animal metaphors. Animal metaphors in literary studies can be related to animal studies. DeMello (2012:4) 
provides the limitation that animal studies are interdisciplinary studies that explore the inhabited areas of animals in the human's socio-cultural world and their interactions. The core of this study is the exploration of how animal's interaction with human. The animal and human relationships can be related to animal rights, human duty to animals, animal behavior in human life, and human behavior in animal life. In addition, the field in animal studies is animal metaphor in literary works.

\section{RESEARCH METHODS}

This study uses qualitative-narrative approach because it uses narrative exposure. This is in line with the Josselson's view (2011) that there are more narrative studies that lead to narration and interpretation in a study.

The data source in this study are Indonesian novels that have relevance to environmental metaphor (Ahmadi, 2017), those are the novel of Burung-Burung Manyar (BbM) (2014), Burung-burung Rantau (BbR) (2014) by YB Mangunwijaya, and Mantra Pejinak Ular (MPU) (2014) by Kuntowijoyo.

The data analysis technique that is used refers to the Miles \& Huberman flow model (1994) related to (1) data collection, (2) data reduction, (3) display data, (4) conclusion drawing and revision. To simplify the analysis, researchers use data encoding.

\section{DISCUSSION}

\section{Animal Methapors}

In art and literature contexts, the animal metaphor is a part of the human and environment interactions. The interactional relationship between human and animal can be viewed from psychological, sociological, or anthropological perspectives. In mythology, humans are portrayed as having affinity with animals, being able to transform into animals, or animals transform into human beings, or half human beings. In literary contexts, humans interpret the animal metaphor and relate it to the environment. The description of the animal metaphor appears in the following $B M$ quotes.

Anak harimau mengamuk. (BbM.Mt.B.01)

Based on the quotation, there is a metaphor about the "little tiger that is raging". Tiger is a wild and strong animal. Therefore, the metaphor illustrates the anger of a young person. The anger of young person is still volatile and strong. The person who has anger is represented by a character named Teto (Indo-Dutch ancestry) who is newly recruited as a KNIL soldier. As a new soldier, he wants to take revenge on what the Japaneses do to his family. He wants to avenge how his father is arrested and tortured by the Japanese army. Moreover, his mother who is caught and become mistress by the Japanese army.

When the figure of Teto, as a male figure, becomes more mature in thinking and acting, he will not be reckless in doing anything including in choosing a woman. He chooses a woman who suits his criteria and he is also known as a lion who wants to find a partner. The description is discussed as follows.

Singa mengerti (BbM.Mt.B.02)
Based on the quote, "lion understands" illustrates the mind-set of Teto character (Lieutenant), KNIL who wants to get Atik by all means. However, with his maturity, he does not want to impose his love for Atik because Atik is on the enemy side (in this context, Atik joins the Republic), while Teto is with the KNIL. That way, he does not want to endanger himself and his unity. As a strong man and a soldier, he has a strong and idealistic soul. Therefore, he also does not want to sacrifice someone for his own sake.

When Indonesian begin to move here and there, the Dutch begin to feel uncomfortable with it. Indonesian freedom fighters begin to intensively attack the Dutch. In a BM novel, the metaphors about the Indonesian fighters' movements are illustrated in the following quotation.

Banteng-banteng muncul (BbM.Mt.B.03)

The quote uses the metaphor of "Bulls appear". Bulls are strong, resilient, and have long horns. Bull is also a symbol of masculinity. The quote is a metaphor for the movements' emergence in Indonesia. One of them is the emergence of General Sudirman, a general who is ready to fight in a guerrilla war against the Dutch army. He willingly to go guerrilla from one forest to another forest.

When there is a battle between the Dutch and Japanese soldiers in Indonesia, the Netherlands are still considered as better figures by Indonesian people. Japan is a country in bandits category because they do a lot of destruction in Indonesia. The image of Dutch attacking the Japanese army appears in the following quotation.

Elang-elang menyerang (BbM.Mt.B.04)

Eagle is a bird species that has predicates of predator, swift, and most feared in bird's world. It describes the attack by the Dutch army against the Japanese army. The eagle is a metaphor of the Dutch planes that attack the Japanese vehicle at that time. In BbM, when the Teto character goes to Kramat Jati, he does not meet Atik. He meets Syahrir, the Prime Minister of the Republic of Indonesia. Atik is the secretary at Syahrir's place. The description is discussed as follows.

\section{Merpati lepas (BbM.Mt.B.05)}

Based on the quotation, it uses "free pigeon". It depicts the Teto character who fails to kill Syahrir (Prime Minister of the Republic of Indonesia). He also fail to ask Atik's condition (Syahrir special assistant) to Syahrir. In fact, he really wants to know the condition.

Macan tutul meraung (BbM.Mt.B.06)

The quote uses leopard metaphor. Leopards are identified with wild and ferocious animals. In the quotation, the leopard metaphor illustrates the KNIL (Dutch) army that attacks the capital city of the Republic of Indonesia. KNIL troops who use the full armaments are capable to paralyze the capital city and arrest Sukarno, Hatta, and Syahrir who are considered great figures in the Republic of Indonesia. When Japan's condition began to falter because of attacks from the Allies, that is the bombing in Nagasaki and Hiroshima cities, Japan begins to be powerless in Indonesia. Therefore, the Japanese troops begin to be withdrawn from Indonesia. In addition, the Japanese army in Indonesia, Keibodan, begins to be dissolved because Japan is no longer able to take care 
of it. Because it is disbanded, the former Keibodan become troublemakers in Indonesia. The description is discussed as follows.

Ayam-ayam disambar. (BbM.Mt.B.07)

Based on the quotation, it appears that the metaphor of "chickens are struck" describes the former Keibodan (Japanese troops, same level as the security) who do thuggery to Indonesia people. They rape, murder, and rob their own nation, the Indonesian nation. They commit acts of thuggery to people who are not on their size, that is why the metaphor of "chicken" usually considered as a weak and easily defeated animal. It is a metaphor that when Indonesia is in chaos, there are some people who take advantage of it as 'strake while the iron is hot'. They are the savage human figures because they commit robbing, destroying, killing and raping. In fact, they rob their own fellow-Indonesian. They do not dare to fight against the invaders.

\section{The Metaphor of Animals and Human Sadness}

When a person is in grief, they can be metaphorized in many ways. One of those sadness metaphors can be attributed to animals. The picture is seen in Marice's character who suffers from sadness. When she is sad, the sadness is metaphorized with animals. The description appears in the following quotation.

Cendrawasih yang terpanah. (BbM. Mt.B.08)

The quotation of the "the bird of paradise that gets shot" in $\mathrm{BbM}$ is a metaphor of Marice, a woman who in the name of love is willingly surrendered herself as a Japanese concubine so that her husband, Brajabasuki, is released by the Japanese. However, Japanese breaks his promise to Marice. Brajabasuki is killed by the Japanese. That is what makes Marice very sad. Because of the protracted sadness, Marice becomes out of her mind. She has given everything to Japanese hoping her husband to be freed. But, in fact Japanese breaks the promise. It is like a bird of paradise. Beautiful bird, but becomes mentally ill because of the death of the person she loves.

\section{Animals Metaphor and the Desire to Get Lover}

In BbR, it tells about the unmarried figure of Teto. In fact, he is in the period to get married. However, he has not made a choice because the girl that he loves marrying another man. Nevertheless, he still longs for a lover. The description appears in the following quotation.

Burung kul yang mendamba (BbM.B.B.09)

The quote "the desiring cow bird" describes the figure of a man who yearns to marry. This picture shows that Teto wants to marry Atik. However, Teto is confused by the desire because he is a person of KNIL who is pro-Dutch, while Atik is a pro-Republican.

\section{Metaphor of Bird's Nest and New Life}

In BbR, the "bird" dictions appear several times. In fact, the title also uses the word of "ostrich birds". In BbR, a diction of a new manyar bird's nest appears. If all this time the man- yar bird already has a nest, now it has a new nest. The new nest is a change that occurs in human beings. The description appears in the following quotation.

Sarang burung manyar baru (BbM Mt.B.10)

Based on the quote, "new manyar bird's nest" metaphor illustrates that the manyar bird has no more nest because in this story, Atik (as a female bird) does not marry Teto. However, in the course of life, it is illustrated that the manyar bird makes a new nest. The new nest is a Teto metaphor that does not marry Atik, but he eventually adopts Atik's children, Mimi, Kris, and Padmi. It is because Atik and her husband passes away during a pilgrimage to the holy land. Thus, the new manyar bird's nest is a metaphor of the Teto character who makes a new place of life, which is the life with Atik's children. The metaphor is also related to "love does not mean together". Teto character cannot love and make Atik as his wife, but he can have her children as his beloved daughters.

Life must go on. It is the same as the experience of Teto. He wants to marry Atik. Apparently, but expectation is not always the same with reality. God has more power for that. Nevertheless, humans should remain grateful for what is happening and what God gives to them. Therefore, Teto remains sincere when Atik is married to another man. In fact, when Atik dies, Teto is willing to take care of Atik's children. That is what is called "new manyar bird's nest" metaphor which represents Teto's story.

\section{Metaphors of Stork and Human Discipline}

Humans in everyday life have similarities with animal behavior. The similarity between humans and animals is a metaphor that humans can be described as animals, either their character or their behavior. The similarities can also be related to the way humans deal with the survival. In BbR, the figure of Prisca is like a white stork. The description appears in the following quotation.

Priska adalah bangau putih kita (BbM Mt.B.11)

Based on the quotation, it is presented that Prisca figure is a metaphor of white stork. In the life of the white storks, they have the character of having precision in determining the time of migration to various regions. That way, the white stork is impossible to mistakenly migrate or be late in migrating to somewhere. In this context, if it is associated with Prisca character, she as a woman who is associated with a white stork because she has the precision of coming to an event. She does not like to come late to an event because she has high discipline about time. The metaphor attached to Prisca is a good animal metaphor because it does not depict a wild or evil beast.

\section{Animal Metaphors and Social Criticism of the Government}

In the MPU, the character of Abu Kasan Sapari raises the wayang (traditional javanese puppet) associated with fable. Wayang with fable characterization rarely appears because this model is the creation result of Abu Kasan Sapari in the world of wayang. He wants the puppets not only be performed for monotone things, but also bring up things that are 
not standard. However, wayang still raises the value of moral and ethical teachings that have spiritual function as well as community entertainment. Abu Kasan Sapari's figure in the MPU distributes the fable puppet with the title "Gajah jadi Raja di Negeri Kambing" (Elephant Be the King in the Land of Goats). The fable can be used as human metaphor in a sociopsychocultural context. The description appears in the following quotation.

"Gajah Jadi Raja di Negeri Kambing” itu begini. Raja Negeri Kambing kosong. Parlemen kambing mengadakan kontes untuk mengisinya. Banyak binatang ikut kontes; dari yang cerdik seperti halnya kancil, yang berbisa seperti halnya ular, yang cepat larinya seperti halnya kijang, sampai yang besar seperti halnya gajah. Parlemen memilih gajah. Mula-mula mereka senang, punya raja yang besar, kuat, dan gagah-perkasa. Akan tetapi, makin lama gajah makin kelihatan belangnya. Gajah mengundang saudara-saudaranya untuk tinggal di Negeri Kambing. (MPU. Mt.B.01)

The characters in the wayang are represented by elephant, goat, snake, mouse deer, deer, and others. It is told that the elephant becomes a king in the animal world not because of a democratic choice, but because of the parliament choice. At first, the king is good, but over time, the king asks its brothers. They do environmental exploitation and the animals are asked to pay tribute.

The animal in wayang is the irony metaphor of the person who becomes the leader. He is elected not by the people democraticly, but by parliament which is in some ways closer to the principle of 'friendship'. When he became ruler, it is his regime that rules all the government wheels. The ruler does corruption, collusion, and nepotism by raising his relatives to become governmental employees. The ruler exploits the environment without regarding to long-term effects, environmental damage, floods, landslides, and extinction. Not only that, the community must give tributes in certain matters, such as in document processing. Society becomes restless and anxious when they are led by this kind of ruler. They feel uncomfortable, insecure, and unhappy because the ruler is not chosen by themselves. Unlike the case when people choose a ruler democraticly, transparently without cheating, people will feel more secure and comfortable. In addition, the animal is also metaphorized as a person's leadership style. The description appears in the following quotation.

Kalau begitu ada tiga gaya orang memerintah. Yaitu memerintah gaya gajah, gaya kuda, dan gaya anjing. (MPU Mt.B.02)

The picture shows that the animal is a metaphor of the lead style and character. When the leader is easy to command, easy to learn, and stupid, they are called elephant style leaders. As they lead by understanding the harmony and balance between superiors and subordinates, they are called horse style leaders. When they lead in a way to be respected, pampered, and lounged, they are referred to as dog style leaders. The elephant and dog metaphors are the pictures of bad and unfit leaders, while the horse metaphor is a good leader and deserves to be one.

Fable or animal are often raised in art/literature as metaphors of human's goodness or badness individually or com- munally. Animals that represent human's badness are rat that is metaphor of corruptor; pig is a metaphor of greedy person; dog is metaphor of bootlicker; duck is metaphor follower; tiger is metaphor of mighty human; and chameleon is metaphor of specious person.

\section{Plant Metaphor}

Plant metaphors in literature can be shown in the metaphors of fruit, flower, or tree. Krupa (2006: 2) explains that in literature, plant metaphors appear in the form of plants, trees, or fungi. The plant metaphor is a figuration of human life, such as "the higher the tree, the greater the wind that blows it." It is the metaphor of human life which means "the more success a person becomes, the more obstacles he gets."

\section{Fruit Metaphor}

In literature, the diction of plants (as part of the environment) can appear literally or metaphorically. The emergence of plant metaphors in literature certainly adds the aesthetic value in the literature. In BM, plant metaphor appears in the form of deciduous fruit. The description appears in the following quotation.

Buah gugur (BbM.Mt.T.01)

Based on the quotation, the metaphor of "fallen fruit" that is used by the author to describe the defeat of the Netherlands against Japan ruinning Teto's life. His happy life changes because of the Netherlands defeat. Because of the lost, his father named Brajabasuki-Dutch KNIL soldier, is arrested by Japanese and his mother named Marice becomes Japanese concubine. Actually, Marice is forced to be concubine and if she does not want to be one, her husband would be killed by the Japanese. The arrest of Brajabasuki ruins Teto's life completely. Therefore, his life is metaphorized with the fallen fruit.

In AAA, Sakatn is a male character who has high ideals. He just wants to get married with woman who fits his criteria. In fact, the woman he wants is very difficult to get. However, Sakatn remains firmly striving to get the woman. The picture appears in the following quotation.

"Kau mengharapkan durian yang manis. Tahu-tahu kau menemukan durian yang pahit...(AAA. Mt.T.01)

The quotation shows that Sakatn wants a woman is metaphorized like a person who is looking for sweet fruit, but what he gets is bitter fruit. The fruit is a metaphor of an overly picky human about a spouse in the hope of getting better one. However, over time, the more Sakatn choose, he does not get better woman, but he gets worse one.

\section{Flower Metaphor}

The grown plant is a metaphor for human. In this case, BbM brings up that kind of metaphor. In many areas, the grown plants are described as something new, beautiful, or fun. The description appears in the following quotation.

Kuncup mekar (BbM, Mt.T.02)

Based on the quotation of "the blooming buds" is a metaphor to illustrate Atik character's growing love to her 
playmate, Teto. Atik falls in love with Teto. As a playmate, Teto is the son of the KNIL soldier who has a handsome and well-built face. Therefore, Atik likes it. In Atik's mind comes what is called the blooming buds. The metaphor of blooming buds is a diction that is related to the appearance of something/the rise of something associated with love. In addition to the blooming buds, the metaphor of the emerging love usually uses the metaphor of blooming flowers and spring flowers.

Atik's feeling towards Teto is not explicitly shown because as a Javanese woman, she is still shy. When Atik's mother, Antana, asks Atik to invite Teto to celebrate her graduation, Atik seems hesitant. She hesitates to reveal her feeling to Teto. It appears in the quote, "Dari sekolah sambil bersepeda Atik tadi juga sudah berpikir, Bu. Teto harus ikut merayakannya. Tetapi, bagaimana caranya? Dan lagi, apa dia mau? "(Mangunwijaya, 2014: 60). Starting from that shows that Atik really has a feeling to Teto.

In human life, flower is often used as a life metaphor. In $\mathrm{BbR}$, it is shown about the flower metaphor associated with the life of Neti figures. The description appears in the following quotation.

Bukankah sering dionggokan tinja sekalipun orang melihat sekuntum bunga memekar, entah dari mana benihnya, dan entah siapa yang menanam, tetapi nyatanya tumbuh? (BbM. Mt.T.03)

Based on the quote, there is a metaphor of "feces that can bring flowers." It shows that even a bad place can bring a good thing. In this case, the metaphor is related to life story of Neti's journey in Calcutta, New Delhi. There, she visits bhangi place with public train. The journey is indeed less fun for Neti. However, behind that, there is a nice thing, her meeting with Krishnahatma. A man who is sympathetic to her.

\section{CONCLUSION}

Based on the exposure, it is concluded that Indonesian authors bring up metaphoric symbols of the environment in the form of animals and plants. The environmental metaphors are related to the philosophy of human life with the environment. In addition, environmental metaphors are also used to criticize humans who exploit the environment or commit corruptions.

\section{REFERENCES}

Ahmadi, A. 2017. Ecopyschology studies in indonesia: film, literature, and education. Beau Bassin: Lambert.

Abrams, M.H. (1999). Glossary of literary terms. Canada: Heinle \& Heinle.

Clark, T. (2015). Ecocriticism on the edge. London: Bloomsbury Publishing.

DeMello, Margo. (2012). Animals and society: an introduction to human-animal studies. New York: Columbia University Press.

Estok, S.C. (2011). Ecocriticism and shakespeare: reading ecophobia. New York: Palgrave.

Garrard, G. (2004). Ecocriticsm. London: Routledge.

Garrard, G. (2012). Teaching ecocriticism and green cultural studies. London: Palgrave.

Josselson, R. (2011). Narrative Research. In F. Wetz Et Al (Ed). Five ways of doing qualitative analysis. London: Guildford.

Khan, R. (2010). Critical pedagogy, ecoliteracy, \& planetary crisis: the ecopedagogy movement. New York: Peter Lang.

Love, G.A. (2003). Practical ecocriticism. London: University of Virginia Press.

Kuntowijoyo. (2016). Mantra pejinak ular. Jakarta: Kompas.

Krupa, V. (2006). Metaphors in maori vocabulary and traditional poetry. Asian and African Studies, 15 (1):18-31.

Mangunwijaya, Y.B. (2014). Burung-burung rantau. Jakarta: Gramedia.

Mangunwijaya, Y.B. (2014). Burung-burung manyar. Jakarta: Gramedia.

Miles, M.B. \& Huberman, A.M. (1994b). Qualitative data analysis. Second Edition. London: Sage Publications.

Punter, D. (2007). Metaphor. London: Routledge. 